\title{
Soil pollution of the Labin city area with polycyclic aromatic hydrocarbons derived from Raša coal mining and associated industries
}

Rudarsko-geološko-naftni zbornik

(The Mining-Geology-Petroleum Engineering Bulletin) UDC: $550: 4$

DOI: 10.17794/rgn.2022.1.12

Original scientific paper

\author{
Ivana Jakovljević'; Ivona Mešićz, Gordana Pehnec ${ }^{1}$ \\ ${ }^{\prime}$ Institute for Medical Research and Occupational Health, Zagreb, Croatia \\ ${ }^{2}$ Bioteka, Zagreb, Croatia
}

\begin{abstract}
The aim of this study was to determine the mass fraction of polycyclic aromatic hydrocarbons (PAHs) in the soil of the Labin city area (west Croatia) as a consequence of the pollution caused by centuries old Raša coal mining and associated metal processing and foundry industries. Samples of topsoil down to a depth of $10 \mathrm{~cm}$ depth, following the removal of plant cover, were collected, air-dried, and sieved to $<2 \mathrm{~mm}$. Afterwards, they were extracted, and PAH levels were measured by high performance liquid chromatography using a fluorescence detector with a varying wavelength of excitation and emission (HPLC/FLD). The results showed substantially elevated levels of PAHs across the study area. The soil pollution with PAHs increased in the direction towards the Raša Bay, where a former coal separation unit was in operation decades ago. The results demonstrated the presence of pyrolitic PAHs that resulted from Raša coal combustion at high temperatures in power plants, and unburnt coal-derived PAHs formed by Raša coal carbonization. For the first time, this paper reports levels of PAHs in soil of the Labin city area, establishing them as higher than the values set by Croatian legislation. Therefore, this study clearly calls for immediate clean-up measures in order to solve the environmental pollution issue of the vulnerable local karst area.
\end{abstract}

Keywords:

Coal combustion; soil pollution; PAHs; power plant; legislation

\section{Introduction}

The use of coal has driven human progress and changed society but has also had multiple negative impacts on the environment, environmental pollution, anthropogenic climate change, and a decrease in resources (Mishra et al., 2019; Saha et al., 2017; Singh et al., 2015; Finkelman et al., 2021). Today, coal is the most common energy raw material, providing $23 \%$ of the world's total primary energy, although, from an environmental point of view, it represents the most dangerous source of energy. Coal is mostly exploited to be used to produce energy in thermal power plants (TPP) whose impact on the environment is very significant. With the development of industry, economy and technology, the need for electricity in the world has significantly increased in the last decades. As a result, the need for fuel is increasing, and consequently, the impact on the environment is growing significantly. The largest percentage in global electricity production is accounted for by coal with as much as $41 \%$, which is more than any other raw material (WCA, 2012). The largest coal market is Asia, where over $50 \%$ of global coal consumption is currently

Corresponding author: Ivana Jakovljević

ijakovljevic@imi.hr consumed (Bogdan et al., 2007). By far, the world's largest coal producer is China, which recorded 3,748 tons of extracted coal in 2014, followed by North America with 916 tons of coal. In Europe, the largest amount of extracted coal was recorded in Germany with 187 tons. The power plant Vlaška (PPV), along with the exploitation of coal, is a large source of hazardous pollutants and elements (Dai et al. 2021). The most represented hazardous pollutants are polychlorinated biphenyls (PCBs) (Dvoršćak et al., 2019) and polycyclic aromatic hydrocarbons (PAHs) (Medunić et al., 2016a; Saikia et al., 2018; Naik, 2019). PAHs are formed during the diagenetic of plant material deep inside the earth crust during maturation, i.e. coal formation (Achten and Hofmann, 2009).

PAHs are organic compounds that consist of two or more aromatic rings. They can be formed during natural processes, such as volcanic eruption or anthropogenically, by human activities. Emissions caused by human activity are much higher than natural emissions. PAH emissions take place due to processes such as the production of coal, crude oil, gasoline and other fuels, natural gas and the production of heavy and light metals (Jakovljević and Žužul, 2011). PAHs are present in exhaust gases, home furnaces, smoked foods, and tobacco and cigarette smoke (Kvesitadze et al., 2006). In urban 
areas, domestic fireplaces, and exhaust fumes of cars with gasoline engines represent the main sources of larger molecular weight PAHs ( $>5$ aromatic rings), while diesel fuels mostly emit smaller molecular weight PAHs (Jakovljević and Žužul, 2011; Jovčić et al., 2012). Also, the coking industry presents a big source of PAHs in the soil. Rachwal et al. (2015) found that the content of PAHs in soil around the coking plant in Zdzieszowice (Poland) was two to three times higher than in other areas, despite a considerably low content of hazardous trace elements (HTEs) in the study area. In almost all of the analyzed samples, PAH contents exceeded national threshold values according to Polish regulations. A study conducted in England showed that in 2010, 76\% of benzo(a)pyrenes entered the environment through combustion from domestic fireplaces, $6.7 \%$ from industrial combustion, $4.3 \%$ from traffic, $3.4 \%$ from metal production, $1 \%$ from waste incineration, and $8.4 \%$ from other sources (Kim et al., 2013).

The PAH emissions from coal-fired power plants are generated by two mechanisms: (1) emissions of incombustible material (fly ash) during the incomplete combustion of coal, and (2) emissions during pyrolysis, which happens in any kind of combustion process (Mastral et al., 2000). Incomplete combustion occurs during the beginning and at the end of a power plant's operation, and also during the repair of certain parts while still under conditions of high temperature. Pyrolysis can lead to different aromatic clusters, thus confirming the already proven possibility of synthesizing benzo[a]pyrene from ethane (Liu et al., 2008).

According to toxicity and their impact on human health, as well as the probability of human exposure to PAHs and their relatively high ambient concentrations, the United States Environmental Protection Agency (EPA) classified sixteen PAHs as primary, most dangerous, environmental pollutants (Liu et al., 2008). PAHs are extremely toxic, mutagenic, and carcinogenic compounds (Yua et al., 2020). Thereby, they are long-term pollutants in the environment where they remain due to their chemical stability and inert characteristics (Jakovljević and Žužul, 2011). Although extremely hydrophobic, PAHs are substantially lipophilic, and in contact with the human body they are absorbed through the lungs, intestines, and skin. Due to their low solubility and high hydrophobicity, they bind rapidly to other organic and inorganic particles in soil (Bihari et al., 2006; Khillare et al., 2013), and are widespread and very stable compounds in the environment. By means of their accumulation in living organisms, their concentrations can be increased in food as a result of contamination by airborne particles (Jakovljević and Žužul, 2011; Kvesitadze et al., 2006).

In Croatia, the surrounding area of the Labin and Raša towns, renowned for its stunning karstic coastline, attracts hundreds of thousands of visitors and tourists per year (see Figure 1). Beyond a narrow scientific community, local residents are far less aware of the scale of the pollution of their immediate environment (Medunić et al., 2020a, b, 2021). Istrian coal mines are located in the Labin region, in the eastern part of Istria, more precisely the area between the river Raša, Čepićko polje, Plomin Bay, the southern part of the Učka massif and the Kvarner Bay (Matijašić, 2005). The soil around TPP Plomin was found to be heavily contaminated with sulfur and PAHs, as well as with ${ }^{226} \mathrm{Ra}$, especially taking into account the direction of prevailing winds in the area, which indicates all the consequences of coal combustion (Medunić et al., 2016b). Halamić and Miko 2009, Miko et al., 2013 partially explored the area of Labin during its geochemical mapping. Lokobauer et al., 1997, determined the highest Rn concentrations in old Labin houses, for whose construction Raša coal ash was crucial, while the houses built later had a significantly lower Rn concentration. Medunić et al., (2016a) determined the degree of the presence of sulfur, PAHs and trace elements in the air, were caused by the combustion of Raša coal with a high concentration of sulfur. There, superhigh-organic-sulfur (SHOS) Raša coal had been exploited for centuries (Medunić et al., 2016b). It is a unique type of coal due to exceptionally high levels of organic S and elevated Se, V, U, and Mo (Medunić et al. 2020b). It is also highly enriched in PAHs (up to 50 $\mu \mathrm{g} / \mathrm{g}$ ), prominently in benzo[a]pyrene $(\mathrm{BaP})$, a potent carcinogen (Medunić et al., 2016a; Roy et al., 2019a). Approximately 40 million tons of SHOS Raša coal was mined and used primarily at local coal-fired power plants until 1999. The geochemical legacy of SHOS Raša coal has affected the composition and toxicity of local soil ever since (Fiket et al. 2020; Medunić et al. 2016a; Radić et al., 2018). For the first time, this paper reports PAH levels in soil (and one stream sediment sample) from the area of the Labin and Raša cities, affected by the legacy of the former SHOS Raša coal industry. The study was carried out with the aim to determine PAHs levels, profiles and possible sources. The results of this study should be used by local authorities to estimate further public health risk assessments and impose environmental remediation measures towards pollution mitigation.

\section{Methods}

The description of methods for determination of PAHs in soils around Raša coal mining was separated into three parts. The first part is related to the site description and sampling strategy, the second part describes the determination of PAHs in soils, including sample preparation and analytical methods used, and the last part comprises the tools used for data analysis.

\subsection{Site description and sampling strategy}

The study area is shown in Figure 1. Karst lithology is host to SHOS Raša coal deposits (Medunić et al., 2016b). Clay-loam soil, characterized by red or brown colour, is composed of boehmite, chlorite, goethite, he- 


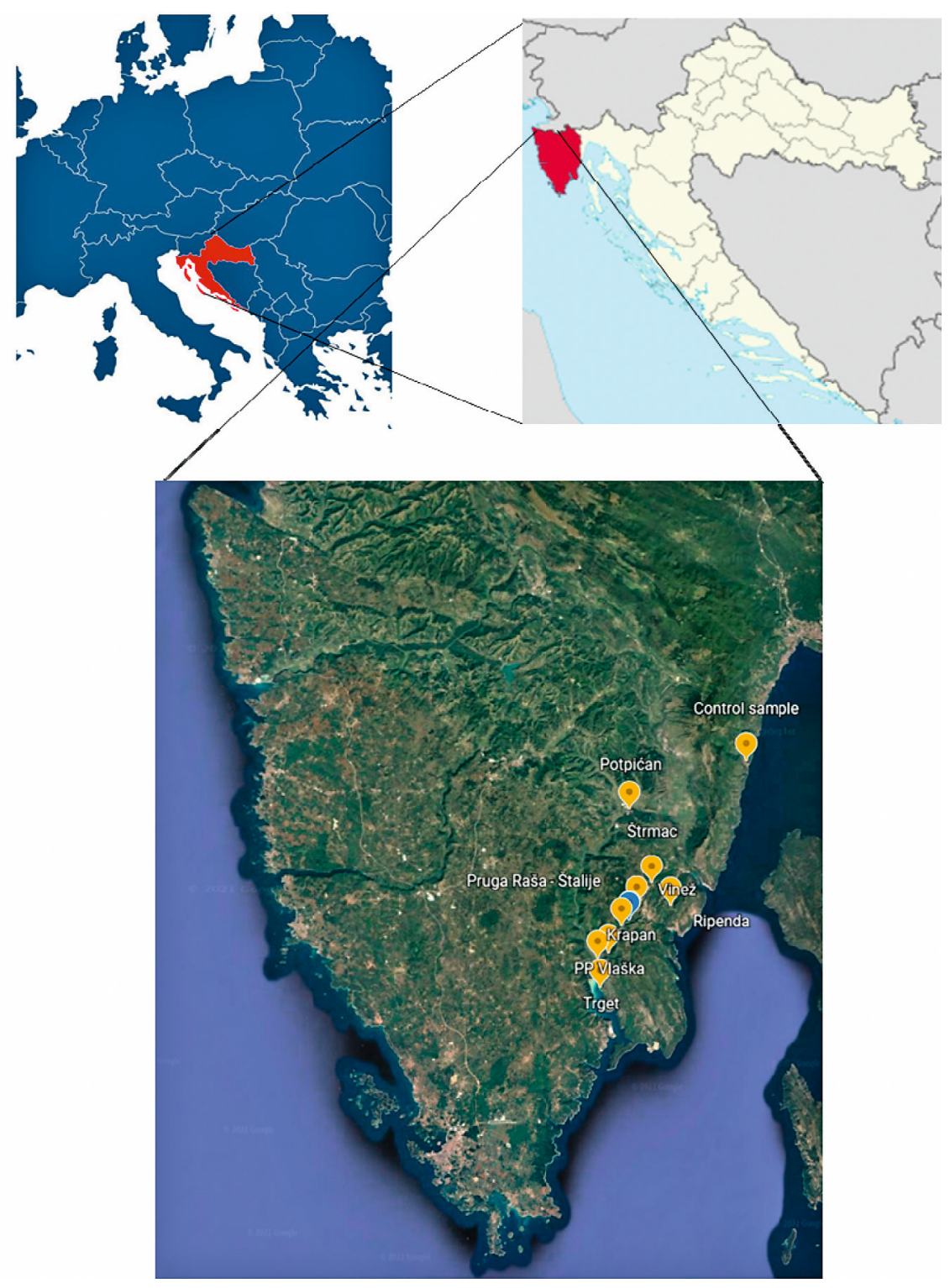

Figure 1: Map of the study area with the locations of the sampling sites

matite, kaolinite, K-feldspar, micas, quartz, vermiculite, and XRD-amorphous components. The study area has been exposed to coal, metal, and foundry industries as well as insufficiently treated municipal wastewater (from the Labin city) for decades. A detailed description of the geology/pedology, sampling strategy, analytical methods, and data characterization (ecological risk assessment) was presented in Medunić et al. (2018). Topsoil $(10-15 \mathrm{~cm})$ samples $(\mathrm{n}=8)$ were collected from locations close to former industrial sites. Measuring sites PP Vlaška 1 (PPV 1), PP Vlaška 2 (PPV 2) and PP Vlaška 3 (PPV 3) were situated near the town of Raša, other sites were related to exploitation of coal. One sample of stream sediment was collected from a sewage channel in the Raša town centre (more details in Medunić et al., 2018). Control topsoil samples $(n=5)$ from the same bedrock were collected $15 \mathrm{~km}$ away from the study area (in reverse direction of the predominant SW wind called bora). Subsequently, the samples taken were air-dried, then gently crushed and sieved through pores of $<2 \mathrm{~mm}$.

\subsection{Analytical methods}

The air-dried and disaggregated soil samples were weighed (corresponding to approximately $5 \mathrm{~g}$ of soil) and extracted in an ultrasonic bath with acetone $(25 \mathrm{~mL})$ for $1 \mathrm{~h}$. After that, extracts were separated from undissolved parts by filtration with a Büchner funnel. The filtrate was evaporated to dryness, and re-dissolved in cyclohexane $(1.5 \mathrm{~mL})$. The cyclohexene samples were purified using adsorption chromatography on a column of fully active silica gel. The aromatic fraction containing all PAHs was obtained by column elution with cyclohexane. This fraction was carefully evaporated to dryness in a nitrogen stream (Wang et al., 2015) and re-dissolved in acetonitrile. Analysis was performed by high-performance liq- 
uid chromatography (HPLC) with a fluorescence detector and programmed changes in excitation and emission wavelengths. PAHs were separated on a Varian stainlesssteel Pursuit 3 PAH column $(100 \times 4.6 \mathrm{~mm})$. The mobile phase was a mixture of acetonitrile and water (60:40), and the flow rate was $0.5 \mathrm{~mL} / \mathrm{min}$. Samples were analyzed for the following PAHs: fluoranthene (Flu), pyrene (Pyr), benzo[a]anthracene (BaA), chrysene (Chry), benzo[e]pyrene $(\mathrm{BeP})$, benzo[b]fluoranthene $(\mathrm{BbF})$, benzo[k]fluoranthene $(\mathrm{BkF})$, benzo[a]pyrene $(\mathrm{BaP})$, dibenzo[ah]anthracene (DahA), benzo[ghi]perilene (BghiP), and indeno[1,2,3,cd]pyrene (IP).

\subsection{Data analysis}

The obtained PAH concentrations, expressed as $\mu \mathrm{g} / \mathrm{g}$, were processed using Statistica 13.1 software (TIBCO Software Inc.). In addition to descriptive analysis, data were subjected to cluster analysis to determine similarities among sampling sites.

\section{Results and discussion}

The concentrations of the analyzed PAHs in the collected soil samples are shown in Table 1. The total concentrations of PAHs ( $\mathrm{PAH})$, expressed as the sum of the measured concentrations of the $11 \mathrm{PAHs}$, varied from $0.25 \mu \mathrm{g} / \mathrm{g}$ (Krapan) to $14.29 \mu \mathrm{g} / \mathrm{g}$ (Trget), while the total PAH concentration in the control soil was 0.03 $\mu \mathrm{g} / \mathrm{g}$. Statistical data analysis (see Table 2) showed that DahA had the lowest average mass concentration $(0.025$ $\mu \mathrm{g} / \mathrm{g}$ ), while the highest average mass concentration was recorded for BaA $(0.752 \mu \mathrm{g} / \mathrm{g})$. The PAHs values in the control soil sample were significantly lower compared to the rest of the analyzed samples (see Table 1). The reason for the lower PAH concentrations in control samples could be because that the control site is protected by the mountain Učka on the west side and by the dominant NE bora wind. According to the Ordinance on the protection of agricultural land from pollution (NN, 2014), this soil can be considered unpolluted.

The contributions of individual PAHs in the sum of total PAHs for each sampling site are shown in Figure 2. The data obtained in Table 2 are between the 25-75\%, and the extreme is $2.35 \mu \mathrm{g} / \mathrm{g}$, recorded for BaA. Concentrations of Flu and Pyr increased from Krapan to Štrmac A (see Figure 1). The reason behind the increase of these concentrations is closely related to the immediate vicinity of TPP Plomin, the work of which is an emission source of various pollutants (Medunić et al., 2016a, b). The direction of the dominant NE wind was precisely in favour of this scheme because the concentrations decreased from the source in the direction of the dominant wind. Coal combustion in the TPP Plomin is a probable source of Flu and Pyr in this study area (Medunić et al., 2016a, b). Individual PAHs show different partitioning behaviour, which may be due to their different chemical affinity and vapor pressure.
The highest contribution in the control sample had Flu (41\%), BbF (13\%) and Pyr (10\%) (see Figure 2). The highest contribution of Flu was recorded at the Krapan $(26 \%)$ site and for Pyr the highest contribution was recorded at Raša-Štalije railway (35\%) (see Figure 2). In addition to Flu and $\mathrm{Pyr}, \mathrm{BaA}$ and $\mathrm{BbF}$ also made a large contribution to the sum of total PAHs at all of the study locations.

The total value of PAHs in the Labin area was 42.2 $\mu \mathrm{g} / \mathrm{g}$, while the total value of PAHs in the soil around the Plomin power plant (formerly powered by Raša coal during the period 1970-2000) was $34.6 \mu \mathrm{g} / \mathrm{g}$ (Medunić et al., 2016a). The maximum value of total PAHs in the samples $(14.29 \mu \mathrm{g} / \mathrm{g})$ investigated in this study was found for the Trget sampling site which is close to the port of Bršica. For centuries, it served as a port for loading Raša coal prior to its shipment to Italy (Medunić et al., 2016a, b). The highest concentrations of $\mathrm{BaA}$ were recorded at the site of Štalije $(2.353 \mu \mathrm{g} / \mathrm{g})$, which is related to the centuries-old purpose of this location; this is where Raša coal was separated from stone and sorted in a modern separation unit (Medunić et al., 2016a, b). The highest concentration of $\mathrm{BbF}$ was measured at the Trget sampling site $(2.316 \mu \mathrm{g} / \mathrm{g})$, which is most likely the result of Raša coal transport to the port of Bršica. The concentrations of $\mathrm{BaP}$ at all of the sampling sites ranged from $0.018 \mu \mathrm{g} / \mathrm{g}$ to $1.264 \mu \mathrm{g} / \mathrm{g}$, which corresponded to the mean values of the concentrations of all analysed PAHs. Even today, the legacy of the transport and loading of large quantities of Raša coal is still present at this location, which can affect the quality of agricultural land as well as human health, through consuming the food grown on the land. For that reason, the PAH concentrations obtained in this study were compared with the Maximum Allowable Concentration (MAC) values (see Table 3 ) set by the Regulation on the protection of agricultural land from pollution (NN 9/14, 2014). At the Trget site, we found that all PAHs except BghiP significantly exceeded the prescribed values; therefore, following the criteria of the Regulations (NN 9/14, 2014), the area can be classified as heavily polluted. In control soil, as well as at sites Ripenda, PP Vlaška 3 and Krapan, none of the measured PAHs exceeded the MAC levels. Regarding the other sampling sites, PAHs varied, i.e. depending on the location, some PAHs exceeded the MAC levels, while others met the criteria of the Regulation (NN 9/14, 2014). Verma et al. (2015) investigated the feed coal, fly ash, and bottom ash from a power plant (Unchahar, India). They found much higher total PAH concentrations in coal $(4542 \mu \mathrm{g} / \mathrm{kg})$ than fly ash $(32.4$ $\mu \mathrm{g} / \mathrm{kg})$ and bottom ash $(10.1 \mu \mathrm{g} / \mathrm{kg})$. High molecular weight PAHs were predominant in coal and fly ash, low molecular weight PAHs were dominant in bottom ash (Verma et al., 2015). Saikia et al., (2016) investigated concentrations of PAHs associated with particle matter (PM) emitted from the tea processing industry which used coal as its energy source. They found that more 
Table 1: PAH concentrations $(\mu \mathrm{g} / \mathrm{g})$ in collected soil and sediment samples

\begin{tabular}{|c|c|c|c|c|c|c|c|c|c|c|c|c|c|}
\hline Site & Flu & Pyr & $\mathbf{B a A}$ & Chry & $\mathrm{BeP}$ & $\mathbf{B b F}$ & BkF & $\mathrm{BaP}$ & DahA & BghiP & IP & ГРАН & $\% \mathrm{BaP}$ in $\Sigma \mathrm{PAH}$ \\
\hline Control sample & 0.01 & 0.00 & 0.00 & 0.00 & 0.00 & 0.00 & 0.00 & 0.00 & 0.00 & 0.00 & 0.00 & 0.03 & 4.5 \\
\hline Štrmac A & 0.48 & 0.76 & 0.50 & 0.06 & 0.14 & 0.50 & 0.12 & 0.21 & 0.03 & 0.44 & 0.19 & 3.43 & 6.2 \\
\hline Štrmac B & 0.29 & 0.42 & 0.26 & 0.03 & 0.07 & 0.26 & 0.07 & 0.11 & 0.02 & 0.10 & 0.08 & 1.70 & 6.6 \\
\hline Ripenda & 0.10 & 0.08 & 0.06 & 0.01 & 0.02 & 0.06 & 0.02 & 0.04 & 0.01 & 0.04 & 0.03 & 0.46 & 7.7 \\
\hline Pruga Raša-Štalije & 0.24 & 0.84 & 0.57 & 0.08 & 0.03 & 0.35 & 0.04 & 0.06 & 0.01 & 0.13 & 0.03 & 2.38 & 2.3 \\
\hline Štalije & 0.57 & 0.10 & 2.35 & 0.34 & 0.09 & 1.16 & 0.10 & 0.20 & 0.02 & 0.11 & 0.05 & 5.11 & 4.0 \\
\hline PP Vlaška 1 & 0.71 & 0.36 & 1.82 & 0.34 & 0.11 & 1.43 & 0.10 & 0.25 & 0.02 & 0.20 & 0.04 & 5.39 & 4.7 \\
\hline PP Vlaška 2 & 1.04 & 0.19 & 1.07 & 0.13 & 0.18 & 1.31 & 0.20 & 0.37 & 0.04 & 0.52 & 0.23 & 5.27 & 7.0 \\
\hline PP Vlaška 3 & 0.16 & 0.19 & 0.06 & 0.02 & 0.03 & 0.08 & 0.03 & 0.06 & 0.01 & 0.07 & 0.05 & 0.76 & 8.0 \\
\hline Krapan & 0.07 & 0.04 & 0.02 & 0.01 & 0.01 & 0.03 & 0.01 & 0.02 & 0.00 & 0.02 & 0.02 & 0.25 & 7.1 \\
\hline Potpićan & 0.28 & 0.55 & 0.63 & 0.12 & 0.06 & 0.45 & 0.03 & 0.07 & 0.01 & 0.06 & 0.02 & 2.27 & 3.0 \\
\hline Vinež & 0.23 & 0.32 & 0.30 & 0.01 & 0.04 & 0.15 & 0.05 & 0.10 & 0.00 & 0.13 & 0.05 & 1.38 & 7.4 \\
\hline Trget & 2.80 & 2.13 & 1.37 & 0.56 & 0.64 & 2.32 & 0.73 & 1.26 & 0.13 & 1.40 & 0.94 & 14.29 & 8.8 \\
\hline Sediment & 0.22 & 0.16 & 0.13 & 0.05 & 0.07 & 0.20 & 0.06 & 0.11 & 0.02 & 0.14 & 0.09 & 1.26 & 0.8 \\
\hline
\end{tabular}

Table 2: Summary statistics of PAH soil concentration data $(\mu \mathrm{g} / \mathrm{g})$ (all sampling sites)

\begin{tabular}{|l|c|c|c|c|c|c|}
\hline PAH & $\mathbf{w}$ & $\mathbf{S T D}$ & $\boldsymbol{\gamma}_{\min }$ & $\boldsymbol{\gamma}_{\max }$ & Lower quartile (Q1) & Upper quartile (Q3) \\
\hline Flu & 0.58 & 0.753 & 0.065 & 2.797 & 0.198 & 0.642 \\
\hline Pyr & 0.497 & 0.574 & 0.043 & 2.127 & 0.143 & 0.652 \\
\hline BaA & 0.752 & 0.754 & 0.016 & 2.353 & 0.162 & 1.224 \\
\hline Chry & 0.142 & 0.177 & 0.008 & 0.559 & 0.015 & 0.234 \\
\hline BeP & 0.119 & 0.173 & 0.013 & 0.642 & 0.03 & 0.124 \\
\hline BbF & 0.675 & 0.719 & 0.029 & 2.316 & 0.112 & 1.232 \\
\hline BkF & 0.126 & 0.199 & 0.011 & 0.735 & 0.032 & 0.112 \\
\hline BaP & 0.229 & 0.342 & 0.018 & 1.264 & 0.058 & 0.232 \\
\hline DahA & 0.025 & 0.035 & 0 & 0.131 & 0.008 & 0.025 \\
\hline BghiP & 0.269 & 0.389 & 0.022 & 1.401 & 0.066 & 0.319 \\
\hline IP & 0.144 & 0.261 & 0.017 & 0.944 & 0.031 & 0.132 \\
\hline
\end{tabular}

$\mathrm{w}$ - average; STD - standard deviation; $\gamma_{\min }-$ minimum; $\gamma_{\max }-$ maximum

volatile PAHs showed higher concentrations in $\mathrm{PM}_{10}$ particles, while higher molecular PAHs mostly bounded to $\mathrm{PM}_{25}$ particles. Concentrations of PAHs under the impact of coal mining were investigated by Yakovleva et al., (2020). They found that concentrations of heavy PAHs in soil were higher near the mine but PAH content in the moss decreased as the distance from the coal mine increased. The results of statistics analysis (see Table 2) showed that the highest PAH concentrations were found for $\mathrm{BaA}$ and $\mathrm{BbF}$, and these compounds, along with Flu and Pyr, were also the most represented in the PAH sum. Because of that, the diagnostic ratios of $\mathrm{BaA} / \mathrm{BaP}, \mathrm{BbF} /$ $\mathrm{BaP}$, and $\mathrm{BbF} / \mathrm{BaA}$ were calculated (see Figure 3). BaP is often used for calculating diagnostic ratios, because it is the most investigated PAH, with the most toxicity information and therefore an indicator of carcinogenic risk in contaminated environments (Roy et al., 2019b; Delgado-Saborit et al., 2011; Wickramasinghe et al., 2011).
Figure 3 shows similar, relatively small $\mathrm{BaA} / \mathrm{BaP}$ ratios at measuring points PP Vlaška 3, Krapan, Trget, sediment, and the control sample. The highest $\mathrm{BaA} / \mathrm{BaP}$ ratio was found at the measuring site Štalije (former Raša coal separation unit), Raša-Štalije railway and Potpićan. These sites, as well as the PP 1 site also recorded the highest $\mathrm{BbF} / \mathrm{BaP}$ ratio. The similarity of ratios at sampling sites Štrmac A, Štrmac B, Ripenda, and PP Vlaška 3 could have probably been due to the fact that these two PAHs (BbF and $\mathrm{BaA})$ came from the same pollution sources. BaA and $\mathrm{BbF}$ are both 5-ring PAHs (high-molecular-weight PAHs) which dominate in coal content (Medunić et al., 2016).

In order to determine the similarity among the sampling sites, the concentrations of PAHs were subjected to cluster analysis, which is a chemometric method of "unsupervised Pattern Recognition", and a cluster is a set of objects more similar to each other than objects outside the set. With the help of one of the selected distance 


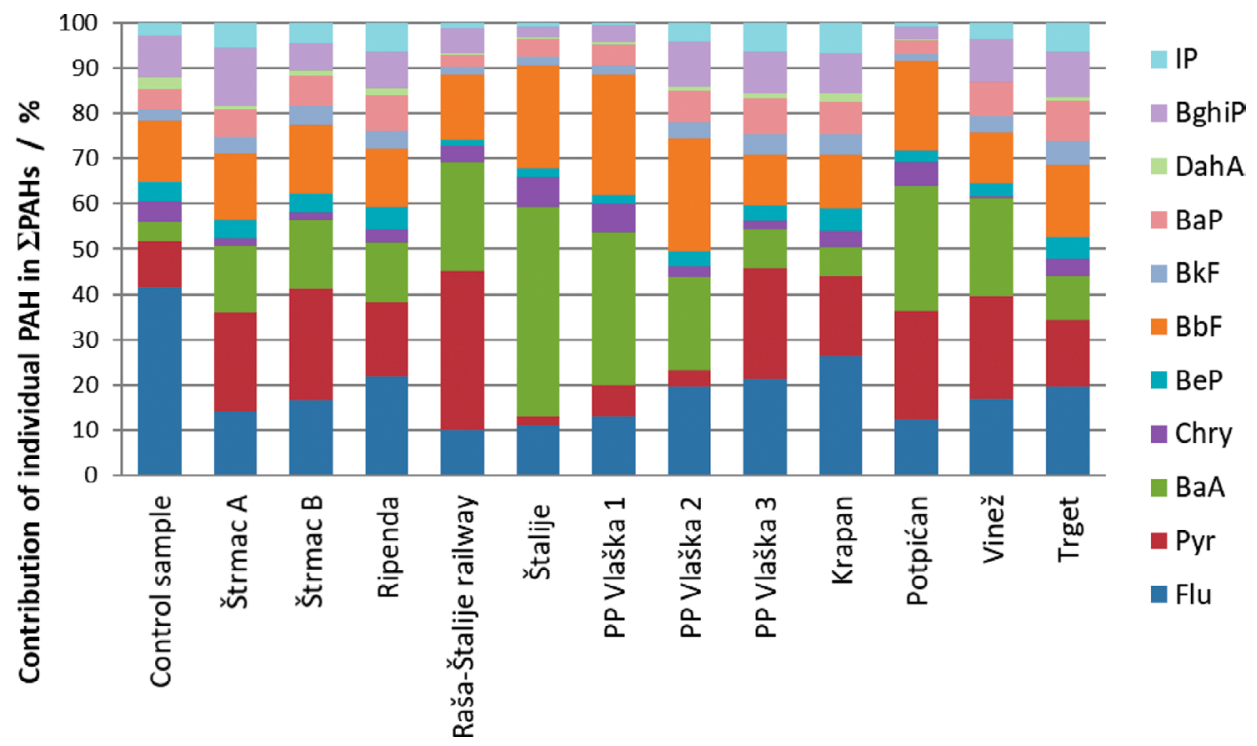

Figure 2: The percentage contribution of individual PAHs to the sum of total PAHs ( $\mathrm{PAH})$ for each sampling site

measures, the similarity matrix, i.e. the difference matrix, was calculated and the Euclidean measure of distance was applied. Figure 4 shows similarities in PAH composition demonstrated by branching on the $\mathrm{Y}$ axis, and their values no matter the distance. From this diagram it is clear that the Trget site was significantly different from all of the other sites, while the composition of PAHs was most similar in the case of the Krapan and Ripenda sites. The most polluted location of the study area was Trget due to the centuries-old practice of loading Raša coal, as well as because of the NE wind, which carried PAHs from the PP Vlaška, similarly like in the case of TPP Plomin (Medunić et al., 2016a). Considering the geographical location and the karst hydrology, PAHs remained intact and undissolved due to the pronounced hydrophobicity. The Krapan and Ripenda sites are most similar in the composition of PAHs because there were Raša coal mines in the past, and the pollutants derived from Raša coal combustion in PP Vlaška did not reach these two sites due to their geographical position and the direction of the dominant NE wind. The consequence of the construction of PP Plomin is visible in the composition of PAHs at these two sampling sites because they are dominated by Pyr and Flu, which are characteristic PAHs formed by coal combustion (Achten and Hofmann, 2009).

The mining shaft of the Ripenda Mine was closed in 1988 after 10 years of operation, while the coal mine in Krapan is the oldest Raša coal mine in the study area, closed after WWII (Medunić et al., 2016b). The Ripenda coal mine worked for a short time, so the concentrations of PAHs at that sampling site would be significantly increased, and on the other hand, the mine in Krapan ended its operation 70 years ago. PP Vlaška was built in Raša Valley in 1939, and it mostly worked for the Raša coal mine, but it was also used as a supplemen- tary source for the needs of the electric power industry. In those years, very little was known about environmental pollutants, so this PP, due to inadequate regulations, left behind a very large area heavily polluted with PAHs as products of coal combustion, but also the very supply of coal wagons in PPs. The cluster analysis also found similarities among the sampling sites PP Vlaška 1 and Štalije, which can be explained by the Raša coal transport from all Raša coal mines to the Štalije site, where Raša coal was separated, sorted, and exported (Bršica port), but part of Raša coal was used for the needs of PP Vlaška. Therefore, it is expected that the composition of PAHs in these two places would be similar due to the use of Raša coal, and due to the proximity of the Štalije and PP Vlaška 1 sites. The similarity of sampling sites at Potpićan and the Raša-Štalije railway is shown on Figure 4. At the Potpićan site, coal mines were used for 40 years, and it was the youngest coal mining settlement in Istria. It was expected that the composition of PAHs corresponding to this mine would coincide with the composition of PAHs on the Raša-Štalije railway due to the transport of Raša coal to the separation site. At the Potpićan site, the soil composition is dominated by the concentration of $\mathrm{BaA}$, which is characteristic of $\mathrm{PAH}$ in the coal composition, while at the Raša-Štalije railway, the highest concentration of Pyr was measured, which was most likely carried by wind from TPP Plomin. Regarding the observed similarity (see Figure 4) in the composition of PAHs at the sites Vinež and Štrmac B, the two sites had the highest concentrations of Pyr, which was most likely due to TPP Plomin, which is located northeast of Štrmac (see Figure 1).

For a better understanding of the PAH sources at the investigated area, we also calculated several diagnostic ratios (see Figure 5). The diagnostic ratios of PAH concentrations in the environmental samples revealed a dif- 

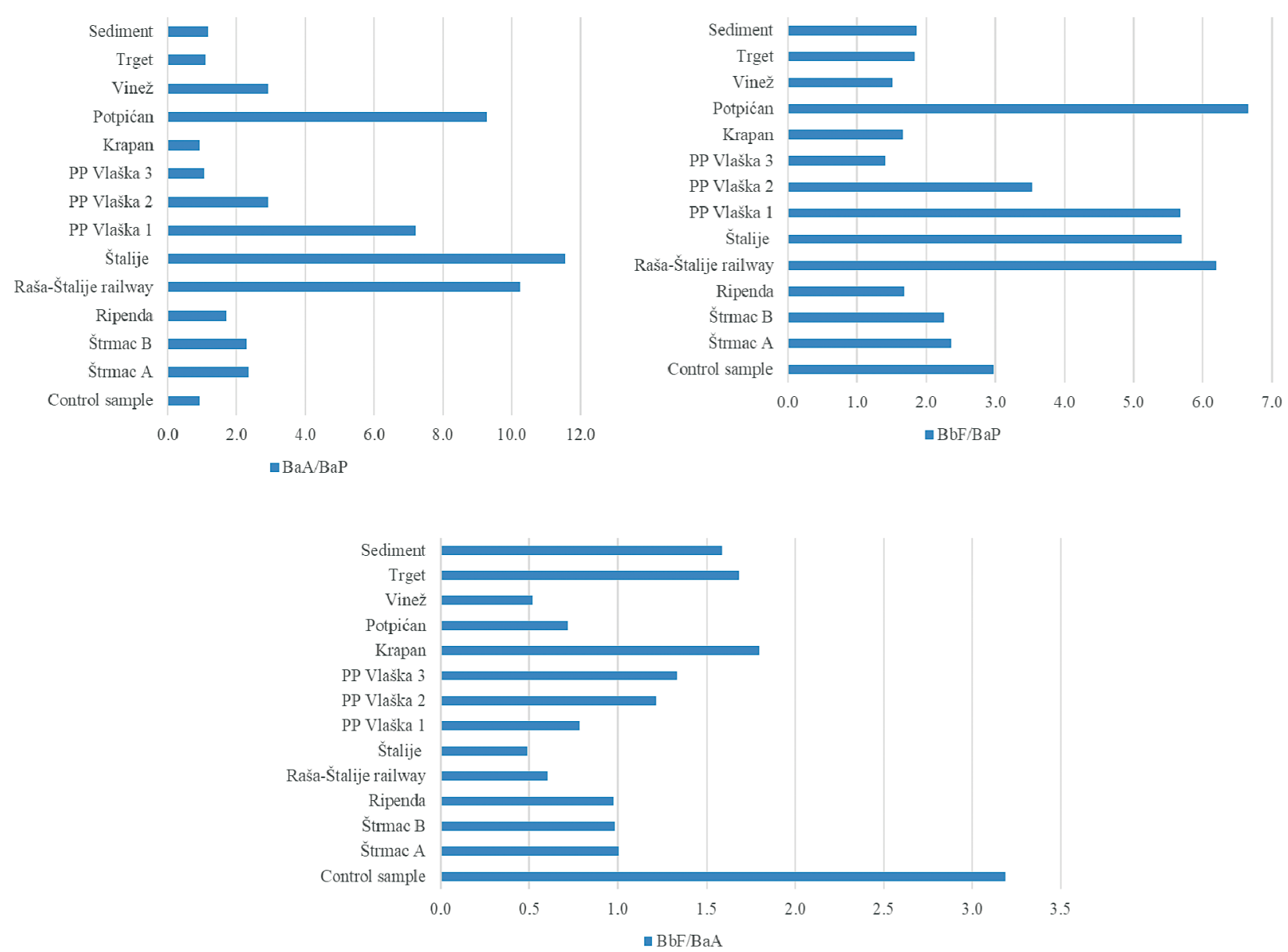

Figure 3: The ratio of $\mathrm{BaA} / \mathrm{BaP}, \mathrm{BbF} / \mathrm{BaP}$ and $\mathrm{BbF} / \mathrm{BaA}$ in the study samples

ferent origin of PAHs in soil. According to Chen et al., (2012), petrogenic sources of PAHs indicate diagnostic ratio of Flu/Pyr $<1$, while values higher than 1 are associated with wood and coal combustion. A Flu/(Flu + Pyr) ratio value lower than 0.5 indicated the petrogenic origin of PAHs, while a value higher than 0.5 pointed to the pyrogenic origin of PAHs (Yakovleva et al., 2020; Gune et al., 2019; Ravindra et al., 2008). Petrogenic sources of PAHs also indicated a $\mathrm{BaA} /(\mathrm{BaA}+\mathrm{Chry})$ ratio lower than 0.2 , but values higher than 0.35 indicated pyrogenic sources (Duodu et al., 2016; Chen et al., 2012). In this study, the ratio of Flu/Pyr was less than 1 at sites Štrmac A and B, Railway Raša-Štalije, PP Vlaška 3, Potpićan and Vinež. Such a value of Flu/Pyr ratio indicated the petrogenic origin of PAHs (Khaustov and Redina, 2017). At the other sites, the Flu/Pyr ratio was higher than 1 which indicated the pyrogenic origin of PAHs (Yakovleva et al., 2020; Migaszewski et al., 2009). The ratio of Flu/(Flu+Pyr) was lower than 0.5 at the same sites as the Flu/Pyr $<1$ ratio which also indicated petrogenic origin PAHs (Gune et al., 2019; Khaustov and Redina, 2017; Ravindra et al., 2008). The pyrogenic origin of PAHs based on the Flu/(Flu+Pyr) ratio was obtained at the Ripeda, Stalije (separation), PP Vlaška 1, PP Vlaška 2, Krapan, and Trget sites, sediment as well as in the control sample. According to a Serbian study, a BaP/BghiP ratio higher than 0.6 indicates vehicle emission. At this investigated area, the railway RašaŠtalije and Štrmac A had a BaP/BghiP ratio below 0.6 which indicated a PAH origin from non-traffic, probably petrogenic sources. The results of diagnostic ratios showed similar results as well as cluster analysis by merging areas with a mostly petrogenic origin of PAHs with a separate area with a pyrogenic origin of PAHs.

The PAHs were presumably formed by Raša coal combustion in TPP Plomin (Medunić et al., 2016a). The sediment sample was taken from the municipal wastewater sewage channel in Raša town, and its composition of PAHs can be connected to the sampling sites Vinež and Štrmac B, but also with the sampling points of PP Vlaška 3, Krapan, and Ripenda. The reason for this is the geographical position of this location, as it is located in the middle of the area that has been under Raša coal mining activities for centuries (Medunić et al., 2016b). Moreover, the concentrations of PAHs measured at this site can be related to traffic, because the D66 State Road is in the immediate vicinity of the sampling site, and as the sample was taken from the stream sediment (Medunić et al., 2018), it was expected that there would be PAHs due to their extreme hydrophobicity. Similarly, Saeedi et al. (2012) found that fossil fuel combustion and the lower quality of petrol used in Tehran were like- 


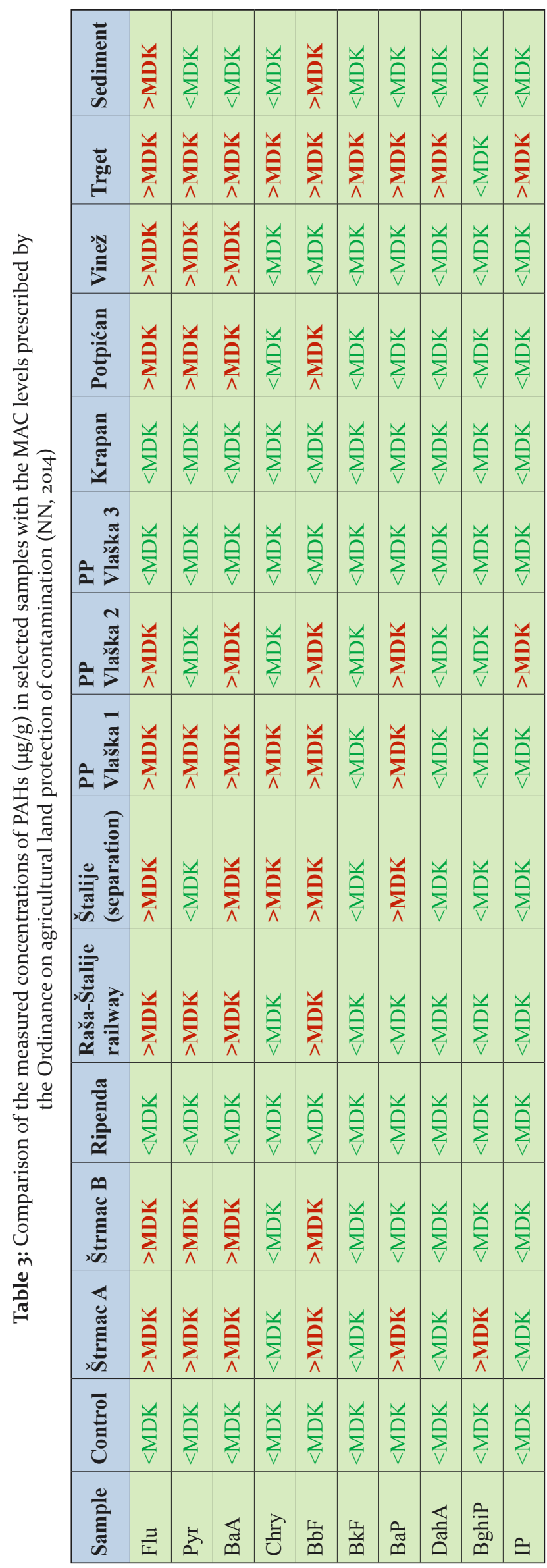

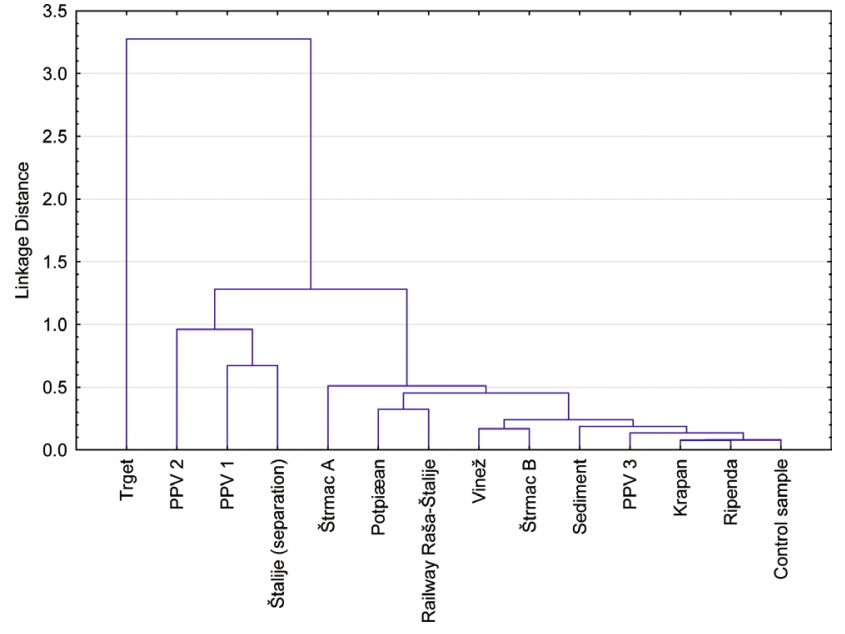

Figure 4: Results of cluster analysis

ly to be among the factors contributing to the high release of PAHs. PAHs may have other petrogenic and sources such as petrol, coal, grass and wood. The maximum concentrations of metals and PAHs were found in dust samples from Baghery highway, one of the most heavily travelled urban roads in Tehran (Saeedi et al., 2012). Also, the other study (Hu et al., 2007) found elevated concentrations of total PAHs, $\mathrm{BaP}$ and $\mathrm{BaPeq}$ at the road intersections $\left(867.5,26.2,82.4 \mathrm{ng} / \mathrm{m}^{3}\right)$, where traffic policemen stood during their work time, compared to the roadside ones $\left(46.6,1.5,5.7 \mathrm{ng} / \mathrm{m}^{3}\right)$.

\section{Conclusions}

In this paper, the levels of PAHs in the area of the Labin and Raša towns are reported for the first time in the context of the former Raša coal mining and associated industries. It was determined that PAH levels in the studied soil are increased due to the legacy of the mentioned industry. Eleven PAHs were detected in the analysed soil, ten of which are on the EPA's list of the 16 most dangerous PAHs. A comparison with the legislation showed that the Trget location is heavily polluted by PAHs, while the places near PP Vlaška (Štalije and the Raša-Štalije railway) are significantly polluted by PAHs. The PAHs in the soil sampling localities decline toward the northeast direction, but by approaching the power plant Plomin proximity, they clearly increase. The results showed the highest quantities of PAHs that dominantly derive from coal (BaA, $\mathrm{BbF})$, and the ones generated by coal combustion in PP Vlaška, and later in PP Plomin (Flu, Pir). Apart from centuries-old Raša coal mining activities and the immediate vicinity of thermal power plants, the influence of dominant air currents also plays an important role in the distribution of PAHs in the study area. Following a comparison between our results and the legislation of the Republic of Croatia, it is clear that the adverse impact of Raša coal mining activities on the environment, especially on soil quality in this area, 

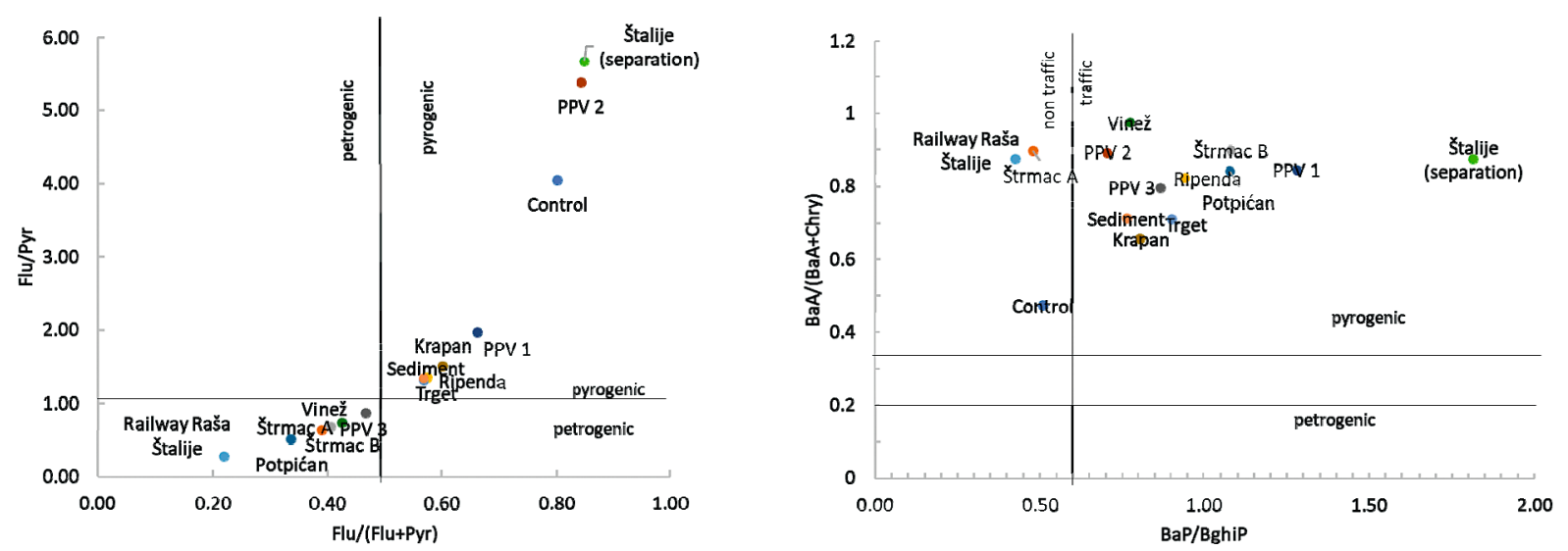

Figure 5: Diagnostic ratio of individual PAHs in soil

has been significant. Therefore, this study clearly calls for immediate clean-up measures in order to solve the environmental pollution issue of the vulnerable local karst area.

\section{Acknowledgment}

The authors thank Mr. Mladen Bajramović (IUR, Istarski ugljenokopi Raša, the town of Raša, Istra, Croatia) for his generous and invaluable help with fieldwork, and ample information about the grand history of Raša coal, a unique type of coal in global terms.

\section{References}

Achten, C. and Hofmann, T. (2009): Native polycyclic aromatic hydrocarbons $(\mathrm{PAH})$ in coals - A hardly recognized source of environmental contamination. Science of the Total Environment 407(8), 2461-2473. https://doi.org/ 10.1016/j.scitotenv.2008.12.008

Bihari, N., Fafanđel, M., Hamer, B. and Kralj-Bilen, B. (2006): PAH content, toxicity and genotoxicity of coastal marine sediments from the Rovinj area, Northern Adriatic, Croatia. Science of the Total Environment 366, 602-611. https://doi.org/10.1016/j.scitotenv.2005.12.001

Bogdan, Ž., Živković, S.A., Dokmanović, V., Merić, J. (2007): Tehnologije čistog ugljena u strategiji razvoja elektroenergetskog sustava. Energija, 56(4), 398-431

Chen, HY. Teng, YG, Wang, JS. (2012): Source apportionment of polycyclic aromatic hydrocarbons (PAHs) in surface sediments of the Rizhao coastal area (China) using diagnostic ratios and factor analysis with nonnegative constraints. Sci TotaL Environ 414, 293-300. https://doi. org/10.1016/j.scitotenv.2011.10.057

Cvetković, A, Jovašević-Stojanović, M, Matić-Besarabić, S, Marković, DA, Bartoñová, A. (2015): Comparison of Sources of Urban Ambient Particle Bound PAHs between Non-Heating Seasons 2009 and 2012 in Belgrade, Srbia. Chemical Industry and Chemical Engineering Quarterly 21(1),211-219. https://doi.org/10.2298/CICEQ140305033C

Dai, S, Finkelman, RB, French, D, Hower, JC, Graham, IT. (2021): Modes of occurrence of elements in coal: A critical evaluation. Earth-Science Reviews 222:103815. https:// doi.org/10.1016/j.earscirev.2021.103815

Delgado-Saborit, JM, Stark, C, Harrison, RM (2011): Carcinogenic potential, levels and sources of polycyclic aromatic hydrocarbon mixtures in indoor and outdoor environments and their implications for air quality standards. Environ Int 37, 383-392. https://doi.org/10.1016/j.envint.2010.10.011

Duodu, GO, Ogogo, KN, Mummullage, S, Harden, F, Goonetilleke, A, Ayoko, GA. (2016): Source apportionment and risk assessment of PAHs in Brisbane River sediment, Australia. Ecological Indicators 73, 784-799. http:// dx.doi.org/10.1016/j.ecolind.2016.10.038

Dvoršćak, M, Stipičević, S, Mendaš, G, Drevenkar, V, Medunić, G, Stančić, Z, Vujević, D. (2019): Soil burden by persistent organochlorine compounds in the vicinity of a coal-fired power plant in Croatia: a comparison study with an urban-industrialized area. Environ. Sci. Pollut. Res. 26(23):23707-23716. https://doi.org/10.1007/s11356019-05605-0

Fiket, Ž., Medunić, G., Vidaković-Cifrek, Ž., Jezidžić, P. and Cvjetko, P. (2020): Effect of coal mining activities and related industry on composition, cytotoxicity and genotoxicity of surrounding soils. Environmental Science and Pollution Research 27(6), 6613-6627. https://doi.org/10.1007/ s11356-019-07396-w

Finkelman, R.B., Wolfe, A. and Hendryx, M.S. (2021): The future environmental and health impacts of coal. Energy Geoscience 2(2), 99-112. https://doi.org/10.1016/j.engeos.2020.11.001

Gune, MM, Ma, WL, Sampath, S, Li, W, Li, YF, Udayashankar, HN, Balakrishna, K, Zhang, Z. (2019): Occurrence of Polycyclic Aromatic Hydrocarbons (PAHs) in Air and Soil Surrounding a Coal-Fired Thermal Power Plant in the South-West Coast of India. Environ. Sci. Pollut. Res. 26 (22), 22772-22782. https://doi.org/10.1007/s11356-01905380-y

Halamić, J., Miko, S. (2009): Geochemical Atlas of the Republic of Croatia. first ed. Croatian Geological Survey, Zagreb.

Hu, Y., Bai, Z., Zhang, L., Wang, X., Zhang, L., Yu, Q. and Zhu, T. (2007): Health risk assessment for traffic police- 
men exposed to polycyclic aromatic hydrocarbons (PAHs) in Tianjin, China. Science of the Total Environment 382, 240-250. https://doi.org/10.1016/j.scitotenv.2007.04.038

Jakovljević, I. and Žužul, S. (2011): Policiklični aromatski ugljikovodici u zraku. Arhiv za higijenu rada i tokiskologiju (Polycyclic aromatic hydrocarbons in the air), 62, 357370. (In Croatian - English abstract). https://doi.org/ 10.2478/10004-1254-62-2011-2095

Jovčić, N.S., Radonić, J.R., Turk Sekulić, M., Vojinović Miloradov, M.B. and Popov, S.B. (2012): Identifikacija izvora emisije čestične frakcije policikličnih aromatskih ugljovodonika u neposrednoj blizini industrijske zone Novog Sada (Identification of Emission Sources Of ParticleBound Polycyclic Aromatic Hydrocarbons in the Vicinity of the Industrial Zone of the City of Novi Sad). Hemijska industrija, 67(2), 337-348. (In Srbian - English abstract)

Khaustov, AP, Redina, MM. (2017): Geochemical Markers Based on Concentration Ratios of PAH in Oils and OilPolluted Areas. Geochemistry International 55 (1), 98107. https://doi.org/10.1134/S0016702916120041

Khillare, P.S., Hasan, A. and Sarkar, S. (2013): Accumulation and risks of polycyclic aromatic hydrocarbons and trace metal sin tropical urban soils. Environmental Monitoring and Assessment, 186(5), 2907-2923. https://doi.org/10. 1007/s10661-013-3589-1

Kim, K.H., Jahan, S.A., Kabir, E. and Brown, R.J.C. (2013): A review of airborne polycyclic aromatic hydrocarbons (PAHs) and their human health effects. Environment International 60, 71-80. https://doi.org/10.1016/j.envint.2013. 07.019

Kvesitadze, G., Khatiasashvili, G., Sadunishvili, T. and Ramsden, J.J. (2006): Biochemical mechanisms of detoxification in higher plants, Springer-Verlag Berlin Heidelberg, $256 \mathrm{pg}$.

Liu, G., Niu, Z., Niekerk, van D., Xue, J. and Zheng, L. (2008): Polycyclic Aromatic Hydrocarbons (PAHs) from Coal Combustion: Emissions, Analysis, and Toxicology. Reviews of Environmental Contamination and Toxycology 192, 1-29. https://doi.org/10.1007/978-0-387-71724-1_1

Lokobauer, N., Franić, Z., Senčar, J., Bauman, A., Sokolović, E. (1997): Radon Concentrations in Houses Around the Plomin Coal-Fired Power Plant. J. Environmental Radioactivity 34, 37-44. https://doi.org/10.1016/0265-931X(96) 00021-5

Mastral, A.M., Callen, M.S. and Garcia, T. (2000): Toxic organic emission from coal combustion. Fuel Processing Technology 67, 1-10. https://doi.org/10.1016/S0378-3820 (00)00088-6

Matijašić, R. (2005): Labinština. Istarska enciklopedija, Leksikografski zavod Miroslav Krleža. Zagreb.

Medunić, G., Ahel, M., Božičević Mihalić, I., Gaurina Srček, V., Kopjar, N., Fiket, Ž., Bituh, T. and Mikac, I. (2016a): Toxic airborne $\mathrm{S}, \mathrm{PAH}$, and trace element legacy of the superhigh-organic-sulphur Raša coal combustion: Cytotoxicity and genotoxicity assessment of soil and ash. Science of the Total Environment 566-567, 306-319. https:// doi.org/10.1016/j.scitotenv.2016.05.096

Medunić, G., Rađenović, A., Bajramović, M., Švec, M. and Tomac, M. (2016b): Once grand, now forgotten: what do we know about the superhigh-organic-sulphur Raša coal? Rudarsko-geološko-naftni Zbornik 31, 27-44. https://doi. org/10.17794/rgn.2016.3.3

Medunić, G., Kuharić, Ž., Krivohlavek, A., Đuroković, M., Dropučić, K., Rađenović, A., Lužar Oberiter, B., Krizmanić, A. and Bajramović, M. (2018): Selenium, Sulphur, Trace Metal, and BTEX Levels in Soil, Water, and Lettuce from the Croatian Raša Bay Contaminated by Superhigh-Organic-Sulphur Coal. Geosciences 8(11), 408. https://doi.org/10.3390/geosciences8110408

Medunić, G., Bucković, D., Prevendar Crnić, A., Bituh, T., Gaurina Srček, V., Radošević, K., Bajramović, M. and Zgorelec, Ž. (2020a): Sulfur, Metal(Loid)S, Radioactivity, and Cytotoxicity in Abandoned Karstic Raša Coal-Mine Discharges (The North Adriatic Sea). Rudarsko-geološkonaftni Zbornik 35(3), 1-16. https://doi.org/10.17794/ rgn.2020.3.1

Medunić, G., Grigore, M., Dai, S., Berti, D., Hochella, M.F., Mastalerz, M., Valentim, B., Guedes, A. and Hower, J.C. (2020b): Characterization of superhigh-organic-sulfur Raša coal, Istria, Croatia, and its environmental implication. International Journal of Coal Geology 217, 103344. https://doi.org/10.1016/j.coal.2019.103344

Medunić, G., Bilandžić, N., Sedak, M., Fiket, Ž., Crnić, A.P. and Geng, V. (2021): Elevated selenium levels in vegetables, fruits, and wild plants affected by the Raša coal mine water chemistry. Rudarsko-geološko-naftni zbornik, 36(1). https://doi.org/10.17794/rgn.2021.1.1

Migaszewski, ZM, Gałuszka, A, Crock, JG, Lamothe, PJ, Dołęgowska, S. (2009): Interspecies and Interregional comparisons of the Chemistry of PAHs and trace elenents in Mosses Hylocomium splendens (Hedw.) B. S. G. and Pleurozium schreberi (Brid.) Mitt. from Poland and Alaska. Atmos Environ 43(7), 1464-1473. https://doi. org/10.1016/j.atmosenv.2008.11.035

Miko, S., Kruk, B., Dedić, Ž., Kruk, Lj., Peh, Z., KovačevićGalović, E., Gabrić, A. (2013): Rudarsko-geološka studija potencijala i gospodarenja mineralnim sirovinama Istarske županije. Hrvatski geološki institute.

Mishra, V., Chakravarty, S., Finkelman, R.B. and Varma, A.K. (2019): Geochemistry of Rare Earth Elements in Lower Gondwana Coals of the Talchir Coal Basin, India. Journal of Geochemical Exploration 204, 43-56. https://doi. org/10.1016/j.gexplo.2019.04.006

Naik, A.S. (2019): Polycyclic aromatic hydrocarbons in Permian coals of India: source and significance. Journal of the Geological Society of India, 94, 579-582. https://doi. org/10.1007/s12594-019-1363-x

Narodne Novine 09/2014 (NN 9/14) (2014): Pravilnik o zaštiti poljoprivrednog zemljišta od onečišćenja.

Rachwał, M., Magiera, T. and Wawer, M. (2015): Coke industry and steel metallurgy as the source of soil contamination by technogenic magnetic particles, heavy metals and polycyclic aromatic hydrocarbons. Chemosphere 138, 863-73. https://doi.org/10.1016/j.chemosphere.2014.11.077

Radić, S., Medunić, G., Kuharić, Ž., Roje, V., Maldini, K., Vujčić, V. and Krivohlavek, A. (2018): The effect of hazardous pollutants from coal combustion activity: Phy- 
totoxicity assessment of aqueous soil extracts. Chemosphere 199, 191-200. https://doi.org/10.1016/j.chemosphere.2018.02.008

Ravindra, K, Sokhi, R, Van Grieken, R. (2008): Atmospheric Aromatic Hydrocarbons: Source Attribution, Emission Factor and Regulation. Atmos. Environ. 42 (13), 28952921. https://doi.org/10.1016/j.atmosenv.2007.12.010

Roy, D., Singh, G. and Seo, Y.C. (2019a): Coal mine fire effects on carcinogenicity and non-carcinogenicity human health risks. Environmental Pollution 254, 113091. https:// doi.org/10.1016/j.envpol.2019.113091

Roy, D., Seo, Y.C., Sinha, S., Bhattacharya, A., Singh, G. and Biswas, P.K. (2019b): Human health risk exposure with respect to particulate-bound polycyclic aromatic hydrocarbons at mine fire-affected coal mining complex. Environmental Science and Pollution Research 26, 19119-19135. https://doi.org/10.1007/s11356-017-9202-3

Saeedi, M., Li, L.Y. and Salmanzadeh, M. (2012): Heavy metals and polycyclic aromatic hydrocarbons: Pollution and ecological risk assessment in street dust of Tehran. Journal of Hazardous Materials 227- 228, 9- 17. https://doi. org/10.1016/j.jhazmat.2012.04.047

Saha, U, Fayiga, A, Sonon, L. (2017): Selenium in the SoilPlant Environment: A Review. Int. J. Appl. Agric. Sci. 3(1):1. https://doi.org/10.11648/j.ijaas.20170301.11

Saikia, J, Khare, P, Saikia, P, Saikia, B. (2016): Polycyclic aromatic hydrocarbons (PAHs) around tea processing industries using high-sulfur coals. Environ. Geochem. Health 39 (5), 1101-1116. https://doi.org/10.1007/s10653-016-9879-0

Saikia BK, Saikia J, Rabha S, Silva LFO, Finkelman R., 2018. Ambient nanoparticles/nanominerals and hazardous elements from coal combustion activity: Implications on energy challenges and health hazards. Geosci. Front. 9(3):863-875. https://doi.org/10.1016/J.GSF.2017.11.013
Singh AL, Singh PK, Singh MP, Kumar A. (2015): Environmentally Sensitive Major and Trace Elements in Indonesian Coal and Their Geochemical Significance. Energy Sources, Part A Recover. Util. Environ. Eff. 37(17):18361845. https://doi.org/10.1080/15567036.2011.646109

Verma, S.K., Masto, R.E., Gautam, S., Choudhury, D.P., Ram, L.C., Maiti, S.K. and Maity, S. (2015): Investigations on PAHs and trace elements in coal and its combustion residues from a power plant. Fuel 162, 138-147. https://doi. org/10.1016/j.fuel.2015.09.005

Wang, R., Liu, G. and Zhang, J. (2015): Variations of emission characterization of PAHs emitted from different utility boilers of coal-fired power plants and risk assessment related to atmospheric PAHs. Science of the Total Environment 538, 180-190. https://doi.org/10.1016/j.scitotenv.2015.08.043

WCA (World Coal Association) (2012): Coal Matters: 1/Coal in the Global Energy Supply.

Wickramasinghe AP, Karunaratne DGGP, Sivakanesan R (2011): PM10-bound polycyclic aromatic hydrocarbons: Concentrations, source characterization and estimating their risk in urban, suburban and rural areas in Kandy, Sri Lanka. Atmos Environ 45, 2642-2650. https://doi. org/10.1016/j.atmosenv.2011.02.067

Yakovleva, EV, Gabov, DN, Kondratenok, BM, Dubrovskiy, YA. (2020): Two-Year Monitoring of PAH in the Soil and Pleurozium schreberi under the Impact of Coal Mining. Polycyclic Aromatic Compounds AHEAD-OF-PRINT 1-16, https://doi.org/10.1080/10406638.2019.1709213

Yua, Y., Sun, X., Zou, L., Zhang, H., Liu, Y. and Liu, M. (2020): Polycyclic aromatic hydrocarbons (PAHs) in surface soil from the Guan River Estuary in China: Contamination, source apportionment and health-risk assessment. Science Asia 46(1), 80-86. https://doi.org/10.2306/scienceasia1513-1874.2020.013 


\section{SAŽETAK}

\section{Zagađenje tla policikličkim aromatskim ugljikovodicima na području grada Labina kao posljedica rudarenja raškoga ugljena i srodnih industrijskih djelatnosti}

Cilj ovoga istraživanja bio je utvrditi maseni udio policikličkih aromatskih ugljikovodika (PAU) u tlu na području grada Labina (zapadna Hrvatska) kao posljedicu onečišćenja uzrokovanoga stoljetnim iskapanjem raškoga ugljena te srodnim metaloprerađivačkim i ljevaoničkim industrijskim djelatnostima. Prikupljeni su uzorci gornjega sloja tla (do $10 \mathrm{~cm}$ dubine) nakon uklanjanja biljnoga pokrova, osušeni na zraku i prosijani kroz sito $<2 \mathrm{~mm}$. Nakon toga su ekstrahirani, a razine PAU-a mjerene su tekućinskom kromatografijom visoke djelotvornosti s fluorescentim detektorom promjenjivih valnih duljina ekscitacije i emisije (HPLC/FLD). Rezultati su pokazali znatno povišene razine PAU-a u istraživanome području. Zagađenje tla PAU-ima raste u smjeru prema Raškome zaljevu, gdje je do prije nekoliko desetljeća radila bivša jedinica za odvajanje ugljena. Rezultati pokazuju prisutnost pirolitičkih PAU-a nastalih izgaranjem raškoga ugljena na visokim temperaturama u elektranama te nesagorjelih PAU-a iz ugljena dobivenih karbonizacijom toga ugljena. Ovo je prvi znanstveni rad koji prikazuje razine PAU-a u tlu na području grada Labina, pronalazeći da one premašuju vrijednosti utvrđene hrvatskim zakonodavstvom. Stoga je ovo istraživanje jasan dokaz da su na tome području potrebne hitne mjere čišćenja (remedijacije) kako bi se riješilo pitanje onečišćenja lokalnoga osjetljivoga krškog okoliša.

\section{Ključne riječi:}

sagorijevanje ugljena, zagađenje tla, PAU, termoelektrana, zakonodavstvo

\section{Author's contribution}

Ivana Jakovljević (Ph. D., Post-doc fellow) - conceptualization, validation of data, investigation, writing - original draft. Ivona Mešić (B.sc.) - formal analysis. Gordana Pehnec (Ph. D., Scientific Associate) - writing, review \& editing. 